\title{
Local and regional energy companies offering energy services: Key activities and implications for the business model
}

\author{
Daniel Kindström and Mikael Ottosson
}

\section{Linköping University Post Print}

\section{Tweet}

N.B.: When citing this work, cite the original article.

Original Publication:

Daniel Kindström and Mikael Ottosson, Local and regional energy companies offering energy services: Key activities and implications for the business model, 2016, Applied Energy, (171), 491-500.

http://dx.doi.org/10.1016/j.apenergy.2016.03.092

Copyright: Elsevier

http://www.elsevier.com/

Postprint available at: Linköping University Electronic Press

http://urn.kb.se/resolve?urn=urn:nbn:se:liu:diva-127223 


\title{
Local and regional energy companies offering energy services: Key activities and implications for the business model
}

\author{
Daniel Kindström* \\ E-mail: daniel.kindstrom@liu.se \\ Mikael Ottosson* (Corresponding author) \\ E-mail: mikael.ottosson@liu.se \\ Phone: +4613282260 \\ *Linköping University, SE-581 83 Linköping, Sweden
}

\begin{abstract}
Energy services play a key role in increasing energy efficiency in the industry. The key actors in these services are the local and regional energy companies that are increasingly implementing energy services as part of their market offering and developing service portfolios. Although expectations for energy services have been high, progress has so far been limited, and many companies offering energy services, including energy companies, are experiencing difficulties in implementing energy services and providing them to the market. Overall, this research examines what is needed for local and regional energy companies to successfully implement energy services (and consequently provide them to the market). In doing this, a two-stage process is used: first, we identify key activities for the successful implementation of energy services, and second, we aggregate the findings to the business model level. This research demonstrates that to succeed in implementing energy services, an energy company may need to renew parts or all of its existing product-based business model, formulate a new business model, or develop coexisting multiple business models. By discussing two distinct business model innovation processes, this research demonstrates that there can be different paths to success.
\end{abstract}

Keywords: energy service, ESCo, activities, energy efficiency, business model, business model innovation 


\section{Introduction}

For many industrial firms, improving energy efficiency is a key strategy leading to direct benefits, such as increased competitiveness (Hirst and Brown, 1990) and productivity (Worrell et al., 2003), and to more indirect environmental benefits (cf. Dangelico and Pontrandolfo, 2013). However, despite a growing interest in finding ways to increase energy efficiency, the industry still harbors untapped energy efficiency potential, conceptualized as energy efficiency and energy service gaps (Hirst and Brown, 1990; Jaffe and Stavins, 1994). These gaps have been explained by factors ranging from market imperfections and asymmetries, through excessive transaction costs and institutional factors, to generally underdeveloped markets (Bertoldi et al., 2006; Painuly et al., 2003; Vine, 2005). As such, existing research tends to be biased toward the market side, and relatively few studies examine the providers, the supply side, of energy efficiency initiatives and the challenges they face in moving toward an increased provision of services.

Companies offering various energy efficiency initiatives to industrial customers do so by means of various energy service offerings. These companies are often referred to as energy service companies (ESCos) (EEC, 2008). ESCos can, for example, be technical consultancies, product manufacturers, and energy companies; and typical activities performed by these actors include energy audits, energy analyses, and implementation of new solutions within customer operations. This research considers a key actor in the energy market and among ESCos: the local and/or regional energy company, that is, the company that produces, sells, and supplies energy. There is a need for research aimed at this type of actors.

Energy services provided by local and regional energy companies have several important macro drivers, ranging from national directives and policies, such as the European Energy Service Directive and the European Energy Efficiency Directive (EC, 2006), to issues such as the greening of company strategies, corporate images, and brands (see, e.g., Dangelico and Pontrandolfo, 2013). From a micro perspective, at the business model level, successfully implemented energy services can offer these energy companies immediate benefits, such as higher margins, differentiation opportunities, and deeper relationships with customers, as well as growth opportunities and new competitive positions.

Examining energy services from the firm-level and business-model perspectives has begun to attract researchers' attention in recent years (e.g., Hannon et al., 2013; Mahapatra et al., 2013; Pätäri and Sinkkonen, 2014; Suhonen and Okkonen, 2013). However, industry progress has 
so far often been limited; and many firms, including energy companies, offering energy services are struggling (Hannon et al., 2013; Pätäri and Sinkkonen, 2014; Suhonen and Okkonen, 2013). Recent findings by Cornelis et al. (2015) reveal that some energy service markets are in fact shrinking, such as those in Belgium, Japan, and Sweden. Identified barriers to the adoption of energy services include distrust toward the providers and high transaction costs in the contractual process (Cornelis et al., 2015), pointing to the need for research focusing on the supply side of energy services and what is needed to succeed from that perspective.

Also, in recent years the business model perspective has been increasingly used to explain changes in the energy sector (Mahapatra et al., 2013). One major barrier to local and regional energy companies' success in implementing energy services is the differences between energy companies' traditional business models and what is referred to as the "ESCo model" (Hannon et al., 2013) (cf., e.g., the study on US utilities by Satchwell et al., 2011). While the traditional business model emphasizes low-cost production and involves little customer interaction, the ESCo model emphasizes holistic energy solutions provided in close interaction with customers.

Rather than focusing on markets and institutions, as much other research does (e.g., Bertoldi et al., 2006; Painuly et al., 2003; Vine, 2005), the focus here is on the actual energy service provider, that is, the energy company, and on the identification of key activities in implementing energy services with the goal of providing energy services to the market. Our overall research aim is to examine what is needed for local and regional energy companies to successfully implement energy services, that is, provide energy services to the market. This aim has been broken down into two specific questions guiding this study: (1) What are the key activities for energy companies to succeed in implementing energy services? (2) What are the consequences of the energy companies' business model? Consequently, in exploring these questions, we use a two-stage process: first, we identify the key needed activities, and second, we aggregate the findings to the business model level.

By conceptualizing the business model as comprising three elements-value proposition, value creation and delivery, and value capture - this article analyzes local and regional Swedish energy companies' implementation of energy services. Given that the Swedish energy sector shares many key characteristics with energy industries in other countries, the results should also be of general interest in the wider international context of energy service transitions. 
This paper is organized as follows: First, we define the energy service concept as well as position our study in relation to previous research around energy services. Second, we review the business model literature and derive our business model conceptualization. Next, in section 4 the method of the paper is presented. The "Results" section (section 5) identifies key activities in implementing energy services within the case companies. Section 6 summarizes the activity configuration identified in section 5 and offers potential managerial outcomes and implications for managers. Finally, section 7 presents the conclusions of the paper.

\section{Energy services: Definition and positioning the paper}

\subsection{Defining the energy service concept}

Energy efficiency can be defined as when a lesser amount of energy is used to sustain a given level of output, or when the same level of energy is used to produce a higher level of output (e.g., IEA, 2012). Improving energy efficiency thus signifies a more efficient utilization of resources, and one way to improve energy efficiency in the energy system is by undertaking investments in energy services. Although the energy service concept was introduced in the early 1980s (Okay and Akman, 2010), today this concept is characterized by definitional confusion (Marino et al., 2011; Pätäri and Sinkkonen, 2014). Table 1 summarizes definitions of energy services presented in some of the most cited journal articles identified using the Web of Science. Note that much research lacks a clear definition and has therefore been excluded.

\section{Table 1}

Energy service definitions.

\begin{tabular}{|l|l|}
\hline Author(s) & Definition of energy service(s) \\
\hline $\begin{array}{l}\text { Greening et al. } \\
(2000), \text { p. } 389\end{array}$ & $\begin{array}{l}\text { "Energy services refer to the commodity, which is actually used or } \\
\text { demanded, i.e., refrigeration, hot water, and process heat. Production of } \\
\text { these commodities requires more than fuel, but also requires the input of } \\
\text { capital, labor, and management expertise by households or firms." }\end{array}$ \\
\hline $\begin{array}{l}\text { Sorrell et al. (2009), } \\
\text { p. } 1357\end{array}$ & $\begin{array}{l}\text { "Energy services such as heating and lighting are provided through energy } \\
\text { systems that involve particular combinations of capital equipment, labor, } \\
\text { materials and marketable energy commodities such as electricity." }\end{array}$ \\
\hline $\begin{array}{l}\text { Bertoldi et al. (2006), } \\
\text { p. } 1820\end{array}$ & $\begin{array}{l}\text { "Energy services include a variety of activities, such as energy analysis and } \\
\text { audits, energy management, project design and implementation, } \\
\text { maintenance and operation, monitoring and evaluation of savings, property } \\
\text { management, and energy and equipment supply." }\end{array}$ \\
\hline
\end{tabular}




\begin{tabular}{|l|l|}
\hline Sorrell (2007), & "Energy service contracting involves the outsourcing of one or more energy- \\
p. 507 & $\begin{array}{l}\text { related services to a third party. In its simplest form, an energy service } \\
\text { contract may guarantee supplies of hot water and/or electricity at reduced } \\
\text { cost, but in a more sophisticated form the contract may guarantee particular } \\
\text { levels of service provision, such as lighting levels, room temperatures, } \\
\text { humidity and 'comfort.' In its most developed form, energy service } \\
\text { contracting allows the client to minimise the total bill for the services that } \\
\text { energy provides through a single contract with an energy services provider." }\end{array}$ \\
\hline
\end{tabular}

As shown in Table 1, the definitions of energy services are wide-ranging. While some of these definitions (e.g., that of Greening et al., 2000) concentrate on the production side of the service, others emphasize the customer side, especially in more complex services (Sorrell, 2007). Bertoldi et al. (2006) state that energy services can range from statistics, audits, management, project design and implementation, and maintenance and operation to various types of energy performance contracts (EPCs). Typically, less complex energy services in Sweden today include energy statistics and information, energy audits, and energy analysis and advice. More advanced services include direct improvement of energy efficiency for the customer, financing of investments for the customer, operations and maintenance, and functional contracts (e.g., contracts agreeing on a set indoor temperature).

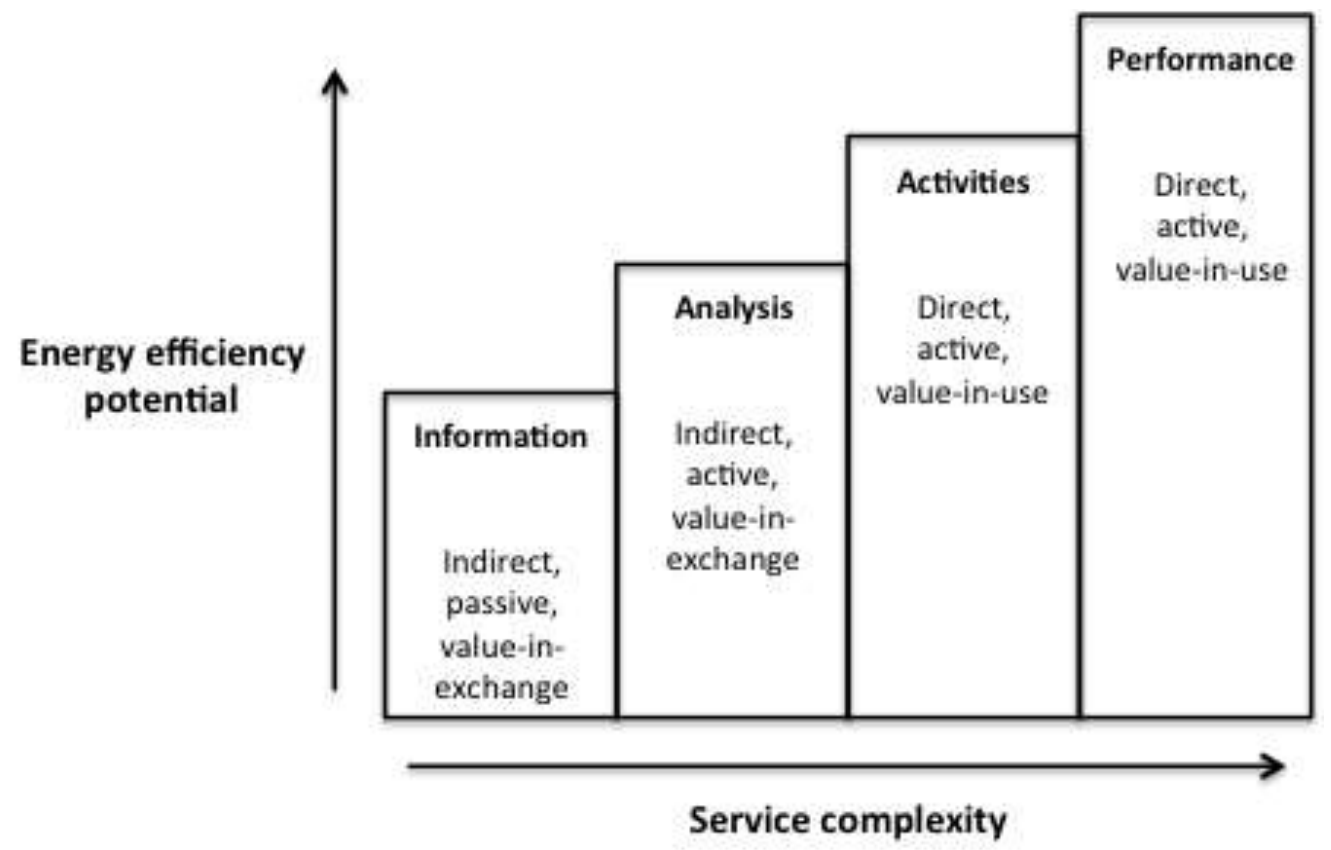

Fig. 1. A classification of energy services.

One way to visualize the various types of energy services, which to the best of our knowledge has not been done in previous research, is to construct a "service ladder" (see Fig. 1). As proposed in Fig. 1, energy services range from information and analysis, through various 
activities and practices, to various types of advanced performance contracts. Even within each of the four steps in the ladder, different types of services are offered by different actors. The service complexity depends on the position in the energy service ladder, increasing from left to right. This also holds for the energy efficiency potential, which increases when it moves up the service ladder. While low-complexity services in the "information" category, such as statistics, have lower energy efficiency potential, more complex services in the "performance" category, such as different versions of EPCs, usually have higher potential while also involving more risk.

Both direct and indirect energy services benefit customers (Bergmasth and Strid, 2004). Direct services are ones that directly and tangibly affect the customer, for example, changing a boiler or optimizing a production process. Indirect services are ones that indirectly and intangibly affect the customer, for example, providing information or analysis on which the customer can subsequently act. Complex services such as facility operations often contain both direct and indirect services. Different services also involve the customer in the value creation process to different degrees. Value propositions in the information and analysis categories emphasize value-in-exchange; that is, they are geared toward a more passive transfer of (potential) value. In the activity and performance categories, the value propositions emphasize value-in-use for the customer instead, and the services often require customer cooperation and participation. Hence, energy services can be defined as services of various complexities that could increase energy efficiency both indirectly and directly.

\subsection{Positioning the study in relation to previous research on energy services}

Much energy service research has focused on describing actual service usage in various countries, regions, or sectors (see, e.g., Bertoldi et al., 2006; Okay and Akman, 2010; Painuly et al., 2003; Vine, 2005) or specific contextual situations (see e.g., Mahapatra et al., 2013). Although these studies find a certain level of growth in energy services, the market growth is often found to be slow and insufficient. Several explanations for this phenomenon have been proposed, and many studies have examined market and public policy issues, for example, advocating public support for ESCos or their customers and decreased legal and institutional barriers (Bertoldi et al., 2006; Painuly et al., 2003).

As noted by Pätäri and Sinkkonen (2014), many studies of energy services have concentrated on evaluating either the outcome of individual energy service projects (Okkonen and Suhonen, 2010; Sovacool, 2013; Wood and Rowley, 2011), specific situations, and the 
inherent business models (such as Mahapatra et al. [2013] and their one-stop-shop business model concept aimed at single-family houses) or the measures needed to improve them (Painuly et al., 2003; Soratana and Marriott, 2010; Sorrell, 2007). In recent years, also more applied simulation models that could potentially be used by energy companies in order calculate the potential performance of EPCs (advanced energy services) have been introduced (see e.g., Deng et al., 2015).

The overall research aim of this paper - to examine what is needed for energy companies to successfully implement energy services and consequently provide them to the market-has been touched on by very few studies (e.g., Hannon et al., 2013; Pätäri and Sinkkonen, 2014; Suhonen and Okkonen, 2013). The few such studies that do exist primarily consider different versions of supply and performance contracts - such as EPCs - even though these constitute only one service type that energy service companies offer (cf. Fig. 1). Furthermore, none of these studies focus on the key activities needed by energy companies in order to effectively offer energy services on the market, while aggregating such findings to the business model level.

\section{Business model innovation and activities needed for offering energy services}

A business model essentially tells a firm's "story" about how it earns money (Magretta, 2002), illustrating how a company creates and captures value (Baden-Fuller and Morgan, 2010). Shafer et al. (2005, p. 202), similarly, define a business model as the "representation of a firm's underlying core logic and strategic choices for creating and capturing value within a value network," and Teece (2010, p. 191) states that a business model can be approached as "the design or architecture of the value creation, delivery and capture mechanisms."

For most companies and in most industries, considering their business models, or stories, as fixed or stable is no longer viable; instead, companies must be able to continuously change and renew their business models through continuous development and innovation. The reasons for this change are multifaceted and could be technological obsolescence, changing customer demands, and the emergence of new value propositions (see, e.g., CasadesusMasanell and Ricart, 2010).

In parallel, or as a consequence, contemporary business models are becoming more complex and paradoxical (Smith et al., 2010), and companies increasingly find themselves having to 
work with multiple business models to address emerging market opportunities and changing customer demands. Companies oftentimes must adopt multiple foci, that is, a "both/and" instead of an "either/or" perspective, even upholding several business models simultaneously (Benson-Rea et al., 2013; Casadesus-Masanell and Tarziján, 2012).

\subsection{Business model innovation}

Business model innovation is increasingly becoming a key element of many companies' overall development and innovation processes, complementing traditional product and service innovation. As Chesbrough (2010, p. 35) argues, "a company has at least as much value to gain from developing an innovative new business model as from developing an innovative new technology." Business model innovation is consequently argued to be pivotal to business success (Zott et al., 2011).

Based on, among others, Teece (2007), we regard business model innovation as a process by which a company introduces change (at some level and of some magnitude or scope) into its business model. Such change can be both evolutionary and adaptive to a changing environment (see, e.g., Doz and Kosonen, 2010; Teece, 2010) or more revolutionary in character (see, e.g., Markides, 2006).

Energy companies extending their businesses by offering energy services need to change their business models; that is, they need to embark on a business model innovation process. Several studies identify the need for multiple simultaneous changes in many elements of a business model during a transition toward the supply of more (energy) services (see, e.g., Gebauer et al., 2005; Kindström and Kowalkowski, 2014; Neu and Brown, 2008). Business model innovation, or change, is increasingly also forwarded as an analytical concept in various energy-related research areas, such as sustainability (Rauter et al., 2015), utilities (Richter, 2012), and energy ecosystems (Hellström et al., 2015).

\subsection{Conceptualizing business models}

Although there are many conceptualizations of the inherent elements of business models and many perspectives of how to approach the business model concept as such (e.g., as an activity system, conceptual tool, or functional map), there are often similarities between the elements of these various conceptualizations, most of which include elements with similar meanings (cf., e.g., Amit and Zott, 2001; Chesbrough and Rosenbloom, 2002; Hamel, 2000; Osterwalder and Pigneur, 2010; Zott and Amit, 2010).

This research takes its starting point from the more general conceptualization that Bocken et 
al. (2014) proposed in their literature review and in their identification of the three core elements of the business model concept, namely, value proposition, value creation and delivery, and value capture (see Table 2) and uses this as a structuring framework. These elements go to the core of many discussions of business models and find parallels in other conceptualizations, for example, in Bohnsack et al.'s (2014) use of the value proposition, value network, and revenue and cost model, as well as Boons and Lüdeke-Freund's (2013) use of the value proposition, supply chain, customer interface, and financial model. These three elements are therefore seen as appropriate for conceptualizing the business model in this research.

\section{Table 2}

The business model conceptualization (Bocken et al., 2014).

\begin{tabular}{|l|l|}
\hline Business model element & Definition \\
\hline Value proposition & Product/service, customer segments, and relationships \\
\hline Value creation and delivery & Key activities, resources, channels, partners, and technology \\
\hline Value capture & Cost structure and revenue streams \\
\hline
\end{tabular}

Numerous conceptualizations adopt a similar structural approach with a limited number of business model elements (cf., e.g., Amit and Zott, 2001, 2010; Bohnsack et al., 2014; Boons and Lüdeke-Freund, 2013; Mason and Spring, 2011; Zott and Amit, 2010). This similarity, among other things, opens up the possibility of analyzing changes in the elements and understanding the interactions between them (Bohnsack et al., 2014), as well as making it useful as a structuring framework.

\section{Method}

As the implementation of strategic initiatives, in this case, energy services by local and regional energy companies, is often a complex process requiring in-depth understanding of underlying, often interrelated, case dimensions (Eisenhardt and Graebner, 2007), we chose a qualitative approach enabling an in-depth understanding of this process.

The three case companies (see Table 3), here denoted case companies A, B, and C, are all large Swedish local and regional energy companies selected from the total population of 
energy companies on the Swedish market. Local and regional utilities have many benefits that their competitors (e.g., technical consultancies) lack, such as unique local and regional customer data on energy use and local presence. Their core businesses (i.e., providing most of the revenue) are district heating and electricity production and sales. To be selected, the chosen firms, first, had to have actively decided to implement energy services and to embark on an implementation journey. Second, the chosen companies had to exhibit tangible interest in increasing their focus on energy services, this being manifested by, for example, energy services being on the firm's strategic agenda or being singled out as a key area for future growth. A third, more pragmatic, selection criterion was that the case companies had to provide access to key informants at several organizational levels.

\section{Table 3}

Brief data on the three case firms.

\begin{tabular}{|c|c|c|c|c|c|c|}
\hline Case & $\begin{array}{c}\text { Turnover, } \\
\text { total } \\
\text { (approx.) }\end{array}$ & $\begin{array}{c}\text { Employees, } \\
\text { total } \\
\text { (approx.) }\end{array}$ & $\begin{array}{c}\text { Turnover, } \\
\text { energy } \\
\text { services } \\
\text { (approx.) }\end{array}$ & $\begin{array}{c}\text { Employees, } \\
\text { energy } \\
\text { services } \\
\text { (approx.) }\end{array}$ & $\begin{array}{c}\text { Energy service } \\
\text { organizational } \\
\text { structure }\end{array}$ & $\begin{array}{c}\text { Energy service } \\
\text { portfolio (cf. Fig. 1) }\end{array}$ \\
\hline A & $\begin{array}{c}\text { EUR 500 } \\
\text { million }\end{array}$ & 1000 & $\begin{array}{c}\text { EUR 0.5 } \\
\text { million }\end{array}$ & 5 & $\begin{array}{c}\text { Separate company } \\
\text { (previously a } \\
\text { separate unit } \\
\text { within another } \\
\text { division) }\end{array}$ & $\begin{array}{c}\text { Offers indirect } \\
\text { services and limited } \\
\text { activity-based direct } \\
\text { services (did }\end{array}$ \\
previously offer a full \\
B
\end{tabular}


For all the three case companies, energy services currently represent a relatively small, but growing, part of the total annual turnover. All the three case companies offer services at all levels in the service ladder (cf. Fig. 1).

In addition to interviewing the respondents from these focal firms, complementary interviews were also held with energy service customers and representatives of other actors supplying energy services, such as technical consultancy companies (see Table 4). This variety of informants enabled a certain level of data triangulation among actors in the energy service value system, improving the researchers' understanding of energy services.

\section{Table 4}

Respondents and their affiliations.

\begin{tabular}{|l|l|l|}
\hline \multicolumn{1}{|c|}{ Affiliation } & Number of interviews & \multicolumn{1}{c|}{ Types of respondents } \\
\hline Case firms & $\begin{array}{l}\text { Case company A: eight } \\
\text { interviews }\end{array}$ & $\begin{array}{l}\text { Senior managers (3 people), head of } \\
\text { energy services (1), service } \\
\text { technicians (2), and energy } \\
\text { experts (2) }\end{array}$ \\
\hline $\begin{array}{l}\text { Case company B: two } \\
\text { interviews }\end{array}$ & $\begin{array}{l}\text { Head of energy services (1 person) } \\
\text { and product manager for energy } \\
\text { services (1) }\end{array}$ \\
\hline $\begin{array}{l}\text { Competitors (e.g., } \\
\text { technical consultancies } \\
\text { and installation firms) }\end{array}$ & $\begin{array}{l}\text { Case company C: five } \\
\text { interviews }\end{array}$ & $\begin{array}{l}\text { Head of energy services (1 person), } \\
\text { energy expert (1), service technician (1), } \\
\text { contract manager (1), and product manager for } \\
\text { energy services (1) }\end{array}$ \\
\hline $\begin{array}{l}\text { Customers (e.g., } \\
\text { private and public } \\
\text { facility owners, } \\
\text { industrial firms) }\end{array}$ & $\begin{array}{l}\text { Consultants (4 firms) and respondents from } \\
\text { installation firms (4) and facility management } \\
\text { firms (2) }\end{array}$ \\
\hline
\end{tabular}

\subsection{Data collection and analysis}

The primary data collection method was semistructured interview (Kvale, 1996) carried out 
with the aid of an interview guide (with primarily open-ended questions ${ }^{1}$ ) based on a theoretical framework structured around the business model conceptualization. Data were collected in 2014. A great majority of the interviews were recorded and transcribed. A few interviews were conducted remotely, which precluded recording them; in those instances, two researchers participated in the interviews, taking detailed notes that were subsequently merged. The respondents from the case companies represented several distinct organizational groupings, including the head of energy services, business developers for energy services, field service for energy services, energy experts, energy engineers, and product managers for energy services, and were primarily chosen for their seniority and extended knowledge of energy services (see Table 4). This range, including respondents from several levels, enabled a certain level of data triangulation within the individual cases (Yin, 2003).

The first step of the data analysis process identified important meanings and themes in the data in order to identify key activities. Individual transcripts and notes were coded for content based on the identified activities and then read in relation to one another, enabling patterns in the implementation of, and activities needed for, energy services to be discerned (Strauss and Corbin, 1990; Yin, 2003). This data analysis method enabled the researchers to detect similarities in the activities discussed by the various respondents and in the strategies and actions of the organizations. The second step then categorized the identified activities according to the business model conceptualization, enabling a business model level analysis and a better understanding of business model innovation.

Within-case analyses were first performed and then merged in a cross-case analysis, as suggested by Eisenhardt (1989). Taking an abductive approach (Dubois and Gadde, 2002) enabled alternation between data and theory, giving a firm grounding in the empirical data as well as establishing links to the theoretical concepts. As a final measure, workshops and industry presentations were held to validate the preliminary results and communicate the findings to the participating companies and to other energy companies on the Swedish market. As previously demonstrated by Stewart and Shamdasani (1990), these workshops and focus group discussions strengthened the analyses as they, for example, enabled the researchers to

\footnotetext{
${ }^{1}$ Some examples of the open-ended questions are the following: What are energy services according to you? What are the main challenges to successfully implementing energy services? What goals do you have in your company regarding energy services and energy efficiency? What are the key factors that need to be in place to successfully implement energy services? Why do you think many energy companies, and other players, find it difficult to implement energy services?
} 
clarify any ambiguities.

\section{Results from the case studies}

To allow a structured discussion, and to link the identified activities to the business model, the activities here are categorized into the three elements of the business model conceptualization (see Table 2) depending on their primary focal point, with one exception. The first activity addressed in this section was deemed an overarching process that did not correspond directly to any one of the business model elements. Instead, it is regarded as an antecedent, or a prerequisite, for successful implementation, touching on the strategic decisions made before the actual configuration and development of the business model elements (CasadesusMasanell and Ricart, 2010; Teece, 2010).

\subsection{An overarching process: establishing a strategic starting point}

In the three case firms, the first initiatives to invest in energy services were primarily ad hoc decisions based on personal interest, or in the sense that the market expected such initiatives of them as energy companies, and not the results of thorough strategic processes. This is not necessarily a problem, but it does necessitate strategic decisions ex post - that is, the company will eventually need to make an active decision regarding its strategic intent (Prahalad and Hamel, 1989). An energy supplier might see several reasons to invest in such services, all of which might have different consequences, for example, for how to design the organizational structure and how to charge, if at all, for the provided energy services.

It has been emphasized that companies should establish a clear strategic intent for services as they extend their portfolios by offering them (Gebauer et al., 2005; Neu and Brown, 2008), among other things, to prevent them from being neglected in companies with a primarily product-oriented culture. The strategic intent of one of the case companies was to generate increased revenue and profitability, while another company's initial intent was to retain customers and create loyalty, primarily to secure its core business. The third case company, on the other hand, struggled with, and was unclear about, its strategic intent and consequently experienced implementation problems because of uncoordinated activities and several false starts. The manager for energy services in one company said, "I would say that they [i.e., energy services] are strategically important, but from an economic perspective, if we compare the different businesses of our firm, we are a drop in the ocean," highlighting the difficulty in acquiring the appropriate support in competition with the core energy business. Similarly, 
illustrating the difficulties, the head of a nonenergy service department said, in relation to energy services, that "the days are filled with activities, and it is difficult to find the motivation to do new things [i.e., energy service-related activities]."

Respondents in all the three case companies emphasized the importance of having a focused strategy implementation process (cf. Gebauer et al., 2005; Neu and Brown, 2008) and of senior management's taking an active leadership of energy services, especially if implementation is to gather momentum and be considered more than a peripheral activity. An energy service manager in one of the case companies explained that "without strong commitment and a clear direction from top management, energy services will never take off."

\subsection{Business model element: value proposition}

\subsubsection{Incrementally adding service content}

Taking a service portfolio approach, two of the case companies used more basic services as a way to build a reputation with customers during the implementation process and to create a foundation for offering more advanced services, sequentially moving up the proposed service ladder (cf. Fig. 1). By approaching the service portfolio in an evolutionary manner, these two case companies were able to build their understanding of energy services and internal organizational demands as well as to create a market presence. Dunford et al. (2010) argues that business model innovation can indeed exhibit the characteristics of an evolutionary process.

This incremental approach permits the establishment of coordination mechanisms (at an operational level) among activities involved in deploying energy services - typically energy service sales, the activities involved in delivering energy services, and the ongoing (often product oriented and related to the core business of supplying energy) operations within the internal organization. One of the case companies, and the head of energy services in that firm, claimed that "it takes a lot of work to get the implementation [of energy services] right" and noted that the processes of coordination and structuring are indeed key issues in an incremental implementation process, especially when scaling up operations from an initially low level. As one solution, the same case company created multiple new energy-servicespecific roles within the organization to manage this coordination and structuring challenge.

One case company simultaneously launched services at all four steps in the service ladder (cf. Fig. 1) and consequently experienced difficulties both in deploying appropriate activities (i.e., 
when to use what resources) and in selling the services (i.e., what to communicate to customers and how). This also created a sense of insecurity among customers as they had difficulties understanding the service portfolio offered.

\subsubsection{Finding the appropriate customers}

Although all suppliers need to segment their markets to identify the most suitable customers, many energy companies have traditionally not prioritized this. One case company, for example, only recently started thinking in terms of segmentation as it realized that not all customers are interested in the full range of energy services. Finding the right customers is crucial as internal resources are often stretched thin and as energy services as a concept are struggling to gain a foothold in the market. For example, although all the case companies perceived various real estate companies as potential key customers, studies demonstrate that the potential might be much higher in the industrial SME sector (Thollander et al., 2007). One case company pursued the real estate segment with its more advanced energy services (i.e., performance contracts) but found it difficult to establish a foothold, eventually realizing that the segment was not interested in such services. Another case company conducted a relatively thorough segmentation and decided to first address key existing customers with whom it had strong relationships; that is, the company made use of the installed customer base in the initial phase (cf., e.g., Ulaga and Reinartz, 2011).

Compared with the traditional energy "product," which is homogeneous and difficult to differentiate, the energy service needs of various customers can be very heterogeneous (Pätäri and Sinkkonen, 2014), offering ample opportunities for segmentation and differentiation. This heterogeneity necessitates a strategy for segmenting and managing customer relationships.

\subsubsection{Making use of the market position}

All the three case companies are established market actors with long histories and strong positions in their respective regional markets, enabling them to use their long-term market presence and links to energy-related issues to access customers. For all three companies, sustainability has also been a major driver in implementing energy services. One of the case companies, for example, uses its positional strategic vision of "being in the center of the most resource-effective region in the world" as a stepping-stone. This type of market position is unique to many energy companies and cannot be easily imitated by competitors, such as consultancy companies, and is an important resource to leverage when implementing energy 
services. In another case company, the energy service product manager added that "energy companies have strong brands but need to protect these by having competent employees," arguing that a strong market position also means that new energy services need to be deployed by competent people so as not to erode that position. Finding the right competences, however, can be difficult.

\subsection{Business model element: value creation and delivery}

\subsubsection{Developing dual competences: strategic and operational}

Many actors, including all the case companies, testify to the challenges of securing access to the competences needed for energy services. In this, distinguishing between strategic and operational competences is possible. Creating value and more advanced energy services calls for both strategic competences, such as the ability to understand the entire energy system, and operational competences, such as the ability to understand and optimize the actual equipment on-site. Many resources and their associated competences, especially operational ones, tend to be highly specialized, for example, concerning ventilation or heating systems. In particular, for more advanced energy services, such as performance contracts including functional agreements (cf. Fig. 1), the studied energy companies need a range of competences covering such areas as emerging energy technologies as well as legal, financial, subcontracting, and project management. Possessing this combination of competences is very rare, and attractive, in the market.

The case companies have used various strategies to address the competence challenge. One strategy seen in all the case companies is to use teams in which several people provide the competences needed, which is becoming increasingly common in sales in other industries (Sheth and Sharma, 2008; Weitz and Bradford, 1999). Another strategy, seen clearly in one of the case companies, is to standardize services. Previous research into energy services has advocated certification and standardization in order to improve the quality of the services sold (Bertoldi et al., 2006; Marino et al., 2011). This would allow energy services further down the service ladder to be delivered by a wider range of resources as the services become more standardized and require less specialized competences. For certain services, such as energy usage information and basic analyses, fully automating delivery is even possible.

\subsubsection{Selling energy services}


Selling services differs from selling products (Grönroos and Ravald, 2011), and previous research has demonstrated that companies' sales organizations undergo major changes when shifting from selling products to selling services (Ulaga and Loveland, 2014). All the three case companies are product-oriented companies that have traditionally focused on selling homogeneous products, often in bulk, but have, to various degrees, dedicated sales resources to energy services. Early in the implementation process, the head of energy services in one of the case companies stated, "We are heavily sales oriented right now. We have six people who are currently selling energy services, so we are working highly proactively. We need to build our own market." Two of the case companies still have dedicated energy service sales resources, but the third company, as part of the efforts to infuse energy services throughout the company, has changed to organization-wide general sales resources managing the company's entire portfolio of products and services. In this third company, it is believed that this change is a major reason for a recent drop in energy service sales, and the energy service product manager stated, "We want to have dedicated sales resources [for energy services]." Another sales-related challenge is that, particularly for more basic energy services such as information and analysis (cf. Fig. 1), extensive sales activities (including multiple customer visits) can quickly erode the relatively small profit margins of energy services. One case company, for example, had to reorganize its sales activities after realizing that the selling process was too costly. Related to this is that the geographical markets in which many municipal energy companies operate are too small to sustain economies of scale related to sales activities for several types of energy services. This implies that suppliers might have to employ different sales resources and processes, and even business models, for different services and/or to standardize certain processes to drive down costs.

\subsubsection{Visualizing the value of energy services}

Gaining market acceptance has been difficult for energy services, and the inability to visualize the value of services has been identified as a potential challenge in other industries (Kindström et al., 2012). Related to this, lack of information concerning energy services and their effects among many potential customers has been identified as a barrier to energy services (Pätäri and Sinkkonen, 2014). Consequently, the ability to visualize the value of energy services, particularly the outcome of more advanced process-oriented energy services, is important and could also function as a key to raising awareness and acceptance on the market. As value is highly contextual (see, e.g., Grönroos, 2008; Vargo and Lusch, 2004), 
this is both a relational issue, that is, understanding the customers and their operations, and a systemic issue, that is, understanding, in depth, the effects and implications of service activities. Developing visualizing tools, as mentioned by potential customers, that can address the lack of trust preventing the adoption of energy services (cf. Sorrell, 2007; Cornelis et al., 2015) is one solution.

\subsection{Business model element: value capture}

\subsubsection{Developing new revenue models}

As the case companies began to offer more advanced services, such as activities and performance contracts (as seen in Fig. 1), they also began to engage more actively with their customers' internal processes. In this, the transition from providing input to a process (with more passive customers) and promising output from a process may create challenges because of the differences between the product and the service perspectives on value creation (Grönroos and Ravald, 2011; Terho et al., 2012), as well as the instilling of trust in the customers. One customer argued that the main "barrier to buying energy services is the fear of letting go of our own control." The companies examined here described this as finding the right "threshold service," that is, identifying the service and the value proposition that allow customers to let the provider into their operational and business processes.

The strategic long-term goal of all the three case companies is to get to the point where their customers' costs are reduced through a more optimal energy use (cf. Bocken et al., 2014). Furthermore, this can allow increased provider profits by means of new revenue models in which the customer, for example, pays for a function (e.g., an agreed-upon indoor temperature) instead of for energy consumption. Ideally, in this scenario, the total energy use will decline through increased energy efficiency at the customer end, and at the same time, the profitability for the energy companies will increase. Very few of these more advanced contracts have been sold by the case companies because of, among other reasons, problems with segmentation, lack of trust, and lack of competence. Respondents from the energy service providers stated, "EPCs are failing on the market" and "we no longer offer performance contracts." In particular, problems agreeing on a baseline with customers were mentioned as a major barrier to more advanced contracts and revenue models by both customers and providers.

\subsubsection{Cost structure}


The cost structure of a business model deploying energy services differs from that of a product-oriented business model. Although lower fixed costs (e.g., for equipment) are typically necessary, higher competence demands increased human resource costs because of, for example, greater demand for multiskilled and flexible employees.

One challenge for the case companies is that of dedicating resources to work exclusively on energy services. One solution to this is to create a common resource base by sharing resources between different business models (cf. Casadesus-Masanell and Tarziján, 2012) or business units. This sharing also creates an increased need for coordination and conflict management as highly attractive internal resources can become production bottlenecks.

\section{Discussion}

\subsection{Underlying activity configuration for energy services}

The "Results" section (section 5) identifies key activities in implementing energy services within the case companies. Table 6 summarizes this activity configuration along with potential managerial outcomes and implications for managers.

\section{Table 6}

Key activities needed and their potential managerial outcomes and possible implications.

\begin{tabular}{|c|l|l|l|}
\hline $\begin{array}{c}\text { Business model } \\
\text { element }\end{array}$ & Activity & Potential managerial outcomes & \multicolumn{1}{|c|}{ Implications for managers } \\
\hline $\begin{array}{c}\text { Overarching } \\
\text { process }\end{array}$ & $\begin{array}{c}\text { Focused } \\
\text { strategic } \\
\text { process }\end{array}$ & $\begin{array}{l}\text { Clearer focus and aim of the } \\
\text { service initiative, as well as } \\
\text { internal strategic leverage }\end{array}$ & $\begin{array}{l}\text { Firm-wide acceptance and } \\
\text { defined goals ensuring } \\
\text { coordinated actions and } \\
\text { resource availability }\end{array}$ \\
\hline $\begin{array}{c}\text { Value } \\
\text { proposition }\end{array}$ & $\begin{array}{c}\text { Adding content } \\
\text { incrementally }\end{array}$ & $\begin{array}{c}\text { Controlled ramp-up and securing } \\
\text { of processes and competences } \\
\text { Finding } \\
\text { customers }\end{array}$ & $\begin{array}{l}\text { Identifying and targeting } \\
\text { appropriate customers } \\
\text { services and necessary internal } \\
\text { resources }\end{array}$ \\
\cline { 2 - 5 } & $\begin{array}{c}\text { Making use of } \\
\text { the market } \\
\text { position }\end{array}$ & $\begin{array}{l}\text { Increasing customer trust in } \\
\text { energy services and increasing } \\
\text { potential size of the market }\end{array}$ & $\begin{array}{l}\text { Approaching the right } \\
\text { customers, thereby increasing } \\
\text { the hit rate and reducing the } \\
\text { costs of energy service sales } \\
\text { and delivery }\end{array}$ \\
\cline { 2 - 4 } & $\begin{array}{l}\text { More cost-effective customer } \\
\text { access and deeper customer } \\
\text { relationships }\end{array}$ \\
\hline
\end{tabular}




\begin{tabular}{|c|c|c|c|}
\hline \multirow[t]{3}{*}{$\begin{array}{l}\text { Value creation } \\
\text { and delivery }\end{array}$} & $\begin{array}{l}\text { Developing } \\
\text { dual } \\
\text { competences }\end{array}$ & $\begin{array}{l}\text { Securing competence and } \\
\text { ensuring value-in-use for } \\
\text { customers }\end{array}$ & $\begin{array}{l}\text { High-value and competent } \\
\text { energy service delivery } \\
\text { ensuring satisfied customers }\end{array}$ \\
\hline & $\begin{array}{l}\text { Selling energy } \\
\text { services }\end{array}$ & $\begin{array}{l}\text { Ensuring successful sales } \\
\text { initiatives and customer } \\
\text { commitment }\end{array}$ & $\begin{array}{l}\text { Ensuring successful sales } \\
\text { initiatives and customer } \\
\text { commitment and increasing hit } \\
\text { rates and customer satisfaction } \\
\text { with energy services }\end{array}$ \\
\hline & $\begin{array}{l}\text { Visualizing } \\
\text { value }\end{array}$ & $\begin{array}{l}\text { Securing sales and customer } \\
\text { understanding of energy services }\end{array}$ & $\begin{array}{l}\text { Customers having awareness } \\
\text { and understanding of the new } \\
\text { value propositions for energy } \\
\text { services, leading to better } \\
\text { market penetration }\end{array}$ \\
\hline \multirow[t]{2}{*}{ Value capture } & $\begin{array}{l}\text { Finding new } \\
\text { revenue model }\end{array}$ & $\begin{array}{l}\text { Developing revenue models } \\
\text { focusing on recurring revenues } \\
\text { with long-term orientation (e.g., } \\
\text { promising output instead of } \\
\text { providing input) }\end{array}$ & $\begin{array}{l}\text { Higher degree of involvement } \\
\text { in customers' internal } \\
\text { processes, providing new } \\
\text { business opportunities and } \\
\text { deeper relationships }\end{array}$ \\
\hline & $\begin{array}{l}\text { Understanding } \\
\text { cost structure }\end{array}$ & $\begin{array}{l}\text { Understanding and minimizing } \\
\text { the cost structure and ensuring an } \\
\text { energy system total cost focus }\end{array}$ & $\begin{array}{l}\text { Better cost control leading to } \\
\text { increased profitability and } \\
\text { increased social and } \\
\text { environmental benefits }\end{array}$ \\
\hline
\end{tabular}

The implementation of energy services holds great potential for energy companies but also presents several challenges. Successful implementation of energy services calls for key activities related to all parts of the business model. Evidence from the cases reported here points to the difficulties of adding energy services without effecting changes to multiple elements of the business model.

All the case companies approached the implementation of energy services as the incremental building of an internal energy service business model (see section 6.2), resulting in the coexistence of dual business models. This entails executing both models identified by Hannon et al. (2013) in parallel. One of the case companies, however, did not manage to develop the needed resources (i.e., did not establish the strategic intent or approach the service portfolio in an evolutionary manner) and subsequently, after several attempts, failed to launch a successful energy service business model. Instead, it opted to create a separate business model through a different business model innovation process (see section 6.3).

\subsection{Business model innovation trajectory I: incremental changes and multiple business} models 
As noted by Doz and Kosonen (2010), a key challenge facing many firms, including energy companies, as they attempt to transform their business models is inertia stemming from a preference for the status quo or the existence of path dependencies (Bohnsack et al., 2014). As energy companies, for the most part, are heavily product centered, often with relatively modest incentives to change, establishing a sense of urgency and the importance needed to foster more radical, frame-breaking change (cf. Tushman et al., 1986) is difficult. Incrementally building a business model based on energy services and establishing the model's strategic intent are thus key tasks. The success of two of the case companies has been driven by the creation of the identified resource configuration (Table 6) and their ability to balance two business models internally. One key factor for one of the successful case companies was early support from top management, for example, in establishing the strategic intent. For the other successful company, key aspects were the incremental approach to the service portfolio and the clear targeting of the existing customer base. This highlights the fact that the innovation process can have different starting points, and foci, within the business model. Because of its successful resource development and business model innovation process, today this case company has a very strong position in its region and is a market leader in energy services.

A key challenge identified in this research, especially pertaining to securing resources and acquiring internal acceptance, is balancing multiple business models. Early in the business model innovation process, this was primarily seen in the difficulties in acquiring the needed resources, whereas later in the process, once the business model was established, this manifested itself in the discussion of the cannibalization of the core business. One case company, being the farthest along in the process, has begun to link these business models in an attempt to create a shared resource base (Casadesus-Masanell and Tarziján, 2012), for example, in sales, as well as to structurally merge parts of the organization.

A key benefit of the incremental process, emphasized by one of the case companies, was the ability to retain control of all aspects of the process and to minimize risk, for example, because of deployment failure or financial exposure. The downside is, of course, that it takes time and losing momentum is easy, as evidenced by the failure of one case company.

\subsection{Business model innovation trajectory II: establishing a separate business model}

One of the case companies made several attempts to establish an energy service business model through an internally oriented incremental process, but it did not succeed. The major reasons for this failure were that the company did not use an evolutionary approach to the 
service portfolio and did not establish a clear strategic intent. To get around these issues, the company decided to embark on another business model innovation process as it established a separate business model detached from the core business model (i.e., the energy utility company model).

Spinning off or separating a service business from a product business has indeed been suggested as one way to manage the service transition problem (cf. Gebauer et al., 2005; Neu and Brown, 2008) and to escape organizational inertia. Key considerations in this, for an energy company, are the very nature of energy services and the fact that a successful service business model will negatively influence the traditional product business model of selling energy, as energy services reduce the customers' need for energy and the associated revenue stream.

Conceptually approaching energy services as a new, separate business model could increase the abilities to mobilize and coordinate resources (cf. Morris et al., 2005) and to identify, develop, and allocate needed strategic and operational competences. For one of the case companies, this is believed to be a viable way to gather momentum and to develop the needed resource configuration, as it experienced difficulties in managing two models internally. Yet another benefit is that the company could create a culture and operational processes without being hampered by existing product-derived path dependencies (Bohnsack et al., 2014). By retaining brand linkages to the energy company, some use could still be made of the existing market position and reputation.

One major challenge facing one of the case companies was establishing a strategic intent, and the separation of the business models addresses this, as the company could then form its energy service strategic intent separately from that of the traditional core business. Potential disadvantages of the separation include lack of financial resources, as now the separated business model cannot rely on the success of the core business model of the energy company, as well as the inherent difficulties of establishing a new presence, and a new company, on the market.

\section{Conclusion}

The overall aim of the research was to examine what is needed for local and regional energy companies to successfully implement energy services and thus to contribute to a more efficient energy system in total. Energy costs in many customers' industries can make up 5\%- 
$15 \%$ of the total added value (Thollander and Ottosson, 2010), and reducing these costs can increase competitive advantage in the future, thus making energy services an interesting aspect for many actors (cf. Rudberg et al., 2013). Energy companies providing energy services offer an opportunity to reduce customers' energy usage, while capturing business opportunities, which may, at the same time, increase revenues.

By identifying and discussing key activities for, and offering managerial input to, the effective implementation of energy services, this research represents a novel attempt to open the preexisting "black box" of the activity configurations underlying these companies' business models. We found that the key activities relate to all parts of the business model and thus necessitate a more holistic approach. Also, our study has demonstrated that to succeed in implementing energy services, an energy company may need to renew parts or all of its existing product-based business model, formulate a new business model, or develop coexisting multiple business models. From a more applied managerial perspective, Table 6 (see section 6.1) summarizes the findings and provides key activities needed in order for managers to succeed in implementing energy services. Potential outcome and implications of these key activities are furthermore pinpointed.

Furthermore, this study provides insights related to international research into energy services. In contrast to the few previous studies applying a business model perspective to energy services, this study analyzes the full service portfolio (cf. Fig. 1) and not only different versions of complex supply and performance contracts such as EPCs. This is an important contribution given that performance contracts still only constitute a minor part of the energy services sold on the Swedish market and that previous research into the European ESCo market has often stated that such contracts are complex to implement. Focusing solely on performance contracts may therefore reduce the total potential of energy services.

Finally, by taking a firm- or business-level approach, this study lays the foundation for the creation of effective energy service provision. From an energy system perspective, the results are of interest as they may facilitate further development of energy services among local and regional energy companies. Such development may not only strengthen these firms' profitability but also increase overall energy efficiency among actors in the energy system by minimizing the cost of energy used to sustain a given level of output or enabling the same level of energy to be used to produce a higher level of output. This study also contributes to the international energy service research field by discussing two distinct business model innovation processes, demonstrating that there can be different paths to success. 
The results can lead to several avenues for future research, including business model development, customer involvement (cocreation), and the strategic maneuvering needed to balance multiple business models. More research is also needed to determine what business model generates the most environmental benefits, linking future research more explicitly to the growing sustainable business model literature (cf. Matos and Silvestre, 2013; Rauter et al., 2015). In such research, optimization as an investment decision support, such as the so-called 'MIND-method', can be used (Thollander et al., 2009).

This research is not without potential limitations. Its qualitative approach and selection of respondents and cases are arguably limiting; and further studies, including those using quantitative methods, are needed to improve our knowledge, generate more opportunities for generalization, and explore certain areas, such as event patterns in the business model innovation process. In addition, as energy services are still a relatively new phenomenon for energy companies, more research is needed, for example, to outline the effects of balancing multiple business models and to map their performance implications more closely. 


\section{References}

Amit R, \& Zott C. (2001). Value creation in e-business. Strategic Management Journal, 22, 493-520.

Aragon-Correa, JA., \& Sharma, S. (2003). A contingent resource-based view of proactive corporate environmental strategy. The Academy of Management Review, 28, 71-88.

Baden-Fuller, C. \& Morgan, M. (2010). Business Models as Models. Long Range Planning, $43,156-171$

Benson-Rea, M, Brodie RJ. \& Sima, H. (2013). The plurality of co-existing business models: Investigating the complexity of value drivers. Industrial Marketing Management, 42, $717-$ 729.

Bergmasth, M. \& Strid, M. (2004) Energitjänster på en avreglerad marknad. För en effektivare energianvändning? Bokförlaget Bas, Handelshögskolan, Göteborg.

Bertoldi, P., Rezessy, S. \& Vine, E. (2006). Energy service companies in European countries: current status and a strategy to foster their development. Energy Policy, 34, 1818-1832.

Bocken, N., Short, S., Rana, P. \& Evans, S. (2014). A literature and practice review to develop Sustainable Business Model Archetypes. Journal of Cleaner Production, 65, 42-56.

Bohnsack, R., Pinkse, J. \& Kolk, A. (2014). Business models for sustainable technologies: Exploring business model evolution in the case of electric vehicles. Research Policy, 43, 284300.

Boons, F. \& Lüdeke-Freund, F. (2013). Business models for sustainable innovation: state-ofthe-art and steps towards a research agenda, Journal of Cleaner Production, 45, 9-19.

Casadesus-Masanell, R. \& Ricart, J. E. (2010). From strategy to business models and onto tactics. Long Range Planning, 43, 105-115.

Casadesus-Masanell, R. \& Tarziján, J. (2012). When one business model isn't enough. Harvard Business Review, Jan/Feb, 132-137.

Chesbrough, H. (2010). Business model innovation: opportunities and barriers. Long Range Planning, 43, 354-363.

Chesbrough, H. \& Rosenbloom, R. S. (2002). The role of the business model in capturing value from innovation: Evidence from Xerox Corporation's technology spin-off companies. 
Industrial and Corporate Change, 11, 529-555.

Cornelis, E., Kimura, O., Karlsson, M., Paramonova, S., Thollander, P., Jiménez Navarro, JP., Morales, I., Weibøl Bertelsen, C (2015). IEA IETS Annex XVI Energy Efficiency in SMEs Task IV: Energy services and business models for industrial SMEs. International Energy Agency, Paris.

Dangelico, R.M. \& Pontrandolfo, P. (2013). Being "green and competitive": the impact of environmental actions and collaborations on firm performance. Bus. Strat. Env. doi: 10.1002/bse. 1828

Deng, Q., Jiang, X., Cuia, Q. \& Zhang, L. (2015). Strategic design of cost savings guarantee in energy performance contracting under uncertainty. Applied Energy, 139, 68-80.

Doz, Y.L. \& Kosonen, M. (2010). Embedding strategic agility: A leadership agenda for accelerating business model renewal. Long Range Planning, 43, 370-382.

Dubois, A. \& Gadde, LE. (2002). Systematic combining: an abductive approach to case research. Journal of Business Research, 55, 553-560.

Dunford, R, Palmer, I. \& Benviste, J. (2010). Business model replication for early and rapid internationalisation: The ING direct experience. Long Range Planning, 43, 655-674.

EC (European Commission) (2006). Directive 2006/32/EC of the European Parliament and of the Council of 5 April 2006 on energy end use efficiency and energy services and repealing Council Directive 93/76/ EEC, Brussels.

EEC (Energy Efficiency Committee). (2008). Vägen till ett energieffektivare Sverige [The road to a more energy efficient Sweden]. SOU 2008:110. Stockholm. [in Swedish].

Eisenhardt, K.M. (1989). Building theories from case study research. Academy of Management Review, 14, 532-550.

Eisenhardt, KM. \& Graebner, ME. (2007). Theory building from cases: opportunities and challenges. Academy of Management Journal 50, 25-32.

Fowler, S. \& Hope, C. (2007). Incorporating sustainable business practices into company strategy. Business Strategy and the Environment, 16, 26-38.

Gebauer, H., Fleisch, E. \& Friedli, T. (2005). Overcoming the service paradox in manufacturing companies. European Management Journal, 23, 14-26.

Greening, L. A., Greene, D. L. \& Difiglio, C. (2000). Energy efficiency and consumption- 
the rebound effect—a survey. Energy Policy. 28. 389 - 401.

Grönroos, C. (2008). Service-dominant logic revisited: who creates value? and who cocreates? European Business Review, 20, 298-314.

Grönroos, C. \& Ravald, A. (2011). Service as business logic: implications for value creation and marketing. Journal of Service Management, 22, 5-22.

Hamel, G. 2000. Leading the Revolution. Harvard Business School Press, Boston.

Hannon, M., Foxon, T. \& Gale, W. (2013). The co-evolutionary relationship between Energy Service Companies and the UK energy system: Implications for a low-carbon transition, Energy Policy, 61, 1031-1045.

Hellström, M., Tevetkova, A., Gustafsson, M. \& Wikström, K. (2015). Collaboration mechanisms for business models in distributed energy ecosystems. Journal of Cleaner Production, 102, 226-236.

Hirst, E. \& Brown, MA. (1990). Closing the efficiency gap: barriers to the efficient use of energy. Resources, Conservation and Recycling, 3, 267-281.

IEA, International Energy Agency. (2012). Spreading the Net: The Multiple Benefits of Energy Efficiency Improvements. Insight Series 2012. Paris, OECD/IEA

Jaffe, A. \& Stavins, R. (1994). The energy-efficiency gap: what does it mean? Energy Policy, $22,804-810$.

Kindström, D., Kowalkowski, C. \& Nordin F. (2012). Visualizing the value of service-based offerings: empirical findings from the manufacturing industry. Journal of Business \& Industrial Marketing, 27, 538-546

Kindström, D. \& Kowalkowski, C. (2014) Service innovation in product-centric firms: A multidimensional business model perspective. Journal of Business \& Industrial Marketing, 29, 96-111

Kvale, S. (1996). Interviews: an introduction to qualitative research. Beverly Hills: Sage publications.

Magretta, J. (2002). Why business models matter?. Harvard Business Review, 80, 86-92.

Mahapatra, K., Gustavsson, L., Haavik, T., Aabrekk, S., Svendsen, S., et al. (2013). Business models for full service energy renovation of single family houses in Nordic countries. Applied Energy. 112, 1558-1565. 
Marino, A,. Bertoldi, P,. Rezessy, S. \& Boza-Kiss, B. (2011). A snapshot of the European energy service market in 2010 and policy recommendations to foster a further market development, Energy Policy, 39, 6190-6198.

Markides, G (2006). Disruptive innovation: In the need for better theory. Joumal of Product Innovation Management, 23(1), 19-25.

Mason, K. \& Spring, M. (2011). The sites and practices of business models. Industrial Marketing Management, 40, 1032-1041.

Matos, S. \& Silvestre, B. (2013). Managing stakeholder relations when developing sustainable business models: the case of the Brazilian energy sector. Journal of Cleaner Production, 45, 61-73.

Morris, M, Schindehutte, MH. \& Allen, J. (2005). The entrepreneur's business model: Toward a unified perspective. Journal of Business Research, 58, 726-735.

Neu, W. \& Brown, S. (2008). Manufacturers forming successful complex business services: Designing an organization to fit the market. International Journal of Service Industry Management, 19, 232-251.

Okay, N. \& Akman, U. (2010) Analysis of ESCO activities using country indicators. Renewable and Sustainable Energy Reviews, 14, 2760-2771.

Okkonen, L., \& Suhonen, N. (2010). Business models of heat entrepreneurship in Finland. Energy Policy, 38, 3443-3452.

Osterwalder, A. \& Pigneur, Y. (2010). Business model generation. Business model foundry, Zurich.

Painuly, J.P., Park, H., Lee, M.K. \& Noh, J. (2003). Promoting energy efficiency financing and ESCos in developing countries: mechanisms and barriers. Journal of Cleaner Production, $11,659-665$.

Penrose, E.T. (1959). The Theory of the Growth of the Firm. Oxford: Oxford university Press. Prahalad, C.K. \& Hamel, G. (1989). Strategic intent, Harvard Business Review, Feb.

Pätäri, S. \& Sinkkonen, K. (2014). Energy Service Companies and Energy Performance Contracting: is there a need to renew the business model? Insights from a Delphi study. Journal of Cleaner Production, 66, 264-271.

Rauter, R., Jonker, J. \& Baumgartner, R. (2015). Going one's own way: drivers in developing 
business models for sustainability. Journal of Cleaner Production, 102, 1-11.

Richter, M. (2012). Utilities' business models for renewable energy: A review. Renewable and Sustainable Energy Reviews, 16, 2483-2493.

Rudberg, M., Waldemarsson, M. \& Lidestam, H. (2013). Strategic perspectives on energy management: A case study in the process industry, Applied Energy, 104, 487-496.

Satchwell, A., Cappers, P. \& Goldman, C. (2011). Carrots and sticks: A comprehensive business model for the successful achievement of energy efficiency resource standards. Utilities Policy, 19, 218-225.

Schneider, S. \& Spieth, P. (2013). Business model innovation: Towards an integrated future research agenda. International Journal of Innovation Management, 17. 1-34

Shafer, S. M., Smith, H. J., \& Linder, J. C. (2005). The power of business models. Business Horizons, 48, 199-207

Sheth, J.N. \& Sharma, A. (2008). The impact of the product to service shift in industrial markets and the evolution of the sales organization. Industrial Marketing Management, 37, 260-269.

Smith, W.K., Binns, A. \& Tushman, M.L. (2010). Complex business models: Managing strategic paradoxes simultaneously. Long Range Planning, $43,448^{\wedge} 61$.

Soratana, K. \& Marriott J. (2010) Increasing innovation in home energy efficiency: Monte Carlo simulation of potential improvements. Energy and Buildings, 42, 828-833.

Sorrell, S. (2007). The economics of energy service contracts. Energy Policy, 35, 507-521.

Sorrell, S., Dimitriopolous J. \& Sommerville M. (2009). Empirical estimates of direct rebound effects: a review. Energy Policy, 37, 1356-1371.

Sovacool, B.K. (2013). Expanding renewable energy access with pro-poor public private partnerships in the developing world. Energy Strategy Reviews, 1, 181-192.

Stewart, D.W. \& Shamdasani, P.N. (1990). Focus groups: Theory and practice. Thousand Oaks, CA: Sage Publications.

Storbacka, K. (2011). A solution business model: Capabilities and management practices for integrated solutions. Industrial Marketing Management, 40, 699-711.

Strauss, A. \& Corbin, J. (1990). Basics of qualitative research: Grounded theory procedures and techniques. London: Sage. 
Suhonen, N. \& Okkonen, L. (2013). The Energy Services Company (ESCo) as business model for heat entrepreneurship-A case study of North Karelia, Finland, Energy Policy, 61, 783-787.

Teece, D.J. (2007). Explicating dynamic capabilities: The nature and microfoundations of (sustainable) enterprise performance. Strategic Management Joumal, 28, 1319-1350.

Teece, D.J. (2010). Business Models, Business Strategy and Innovation. Long Range Planning, 43.

Terho, H., Haas, T., Eggert, A., \& Ulaga, W. (2012). “It's almost like taking the sales out of selling": towards a conceptualization of value-based selling in business markets. Industrial Marketing Management, 41, 174-185.

Thollander P. \& Ottosson M. (2010). Energy management practices in Swedish energyintensive industries. Journal of Cleaner Production, 18, 1125-33.

Thollander. P., Rohdin, P. \& Danestig, M. (2007). Energy policies for increased industrial energy efficiency: Evaluation of a local energy programme for manufacturing SMEs. Energy Policy, 35, 5774-5783.

Thollander P., Mardan N., Karlsson M. , (2009) Optimisation as investment decision support in a Swedish medium-sized iron foundry - a move beyond traditional energy auditing, Applied Energy, 86, 433-440.

Tushman, M.L., Newman, W.H. \& Romanelli, E. (1986). Convergence and Upheval: Managing the Unsteady Place of Organizational Evolution. California Management Review, 29, 29-44.

Ulaga, W. \& Reinartz, W. (2011). Hybrid offerings: how manufacturing firms combine goods and services successfully. Journal of Marketing, 75, 5-23.

Ulaga, W. \& Loveland, J. M. (2014), Transitioning from product to service-led growth in manufacturing firms: emergent challenges in selecting and managing the industrial sales force, Industrial Marketing Management, 43, 113-125.

Vargo, S.L. \& Lusch, R.F. (2004). Evolving to a new dominant logic for marketing, Journal of Marketing, 68, 1-17.

Vine, E. (2005). An international survey of the energy service company ESCO industry. Energy Policy, 33, 691-704. 
Weitz, B.A. \& Bradford, K.D. (1999). Personal selling and sales management: A relationship marketing perspective. Journal of the Academy of Marketing Science, 27, 241-254.

Wood, S.R. \& Rowley, P.N. (2011). A techno-economic analysis of small-scale, biomassfuelled heat and power for community housing. Biomass Bioenergy, 35, 3849-3858.

Worrell, E., Laitner, J., Ruth, M. \& Finman, H. (2003). Productivity benefits of industrial energy efficiency measures. Energy, 28, 1081-1098.

Yin, RK. (2003). Case study research, design and methods. Newbury Park: Sage

Publications.

Zott, C., Amit, R. (2010). Business model design: an activity system perspective. Long Range Planning, 43, 216-226.

Zott, C., Amit, R., \& Massa, L. (2011). The business model: recent developments and future research. J. Manag., 37, 1019-1042. 